\title{
Myxidium rhodei (Protozoa: Myxozoa: Myxosporea) in cyprinid fish from NW Spain
}

\author{
P. Alvarez-Pellitero \\ Instituto de Acuicultura Torre de la Sal (CSIC), Castellón, Spain
}

\begin{abstract}
Myxidium rhodei infection of the kidney of chub Leuciscus cephalus cabeda and boga Chondrostoma polylepis from the Esla River, Spain is described. Prevalence was low, $3.8 \%$ in chub and $1 \%$ in boga, and intensity relatively high. Affected kidneys exhibited varying degrees of histopathological damage. Spores and plasmodia of the parasite were found mainly in the interstitia, but also in the glomeruli, frequently encapsulated in granulomas with an intense fibrotic reaction. A granulomatous inflammatory reaction with leucocytic infiltration was evident around cysts, affected glomeruli or plasmodia. As a result, much of the kidney tissue became seriously damaged
\end{abstract}

\section{INTRODUCTION}

Myxidium rhodei Lèger, 1905 has been found in numerous fish species (Shulman 1984) and, according to Jayasi \& Hoffman (1982) has a wide geographical distribution. Nevertheless, most reports concerning this species are merely host or geographical records. Dykova et al. (1987) gave information on $M$. rhodei pathogenicity in roach, together with structural data, and pointed out the need for research on its pathological effects on other fish species.

In the present paper, we report the presence of $M y X-$ idium rhodei in 2 fish species from the Iberian peninsula. The parasite is described and histopathological effects on the host kidney are discussed.

\section{MATERIAL AND METHODS}

We examined 85 chub Leuciscus cephalus cabeda Risso ( 1 to 7 yr old, 12 to $23.5 \mathrm{~cm}$ length) and 90 boga Chondrostoma polylepis Steind. (1 to 5 yrold, 16 to $28 \mathrm{~cm}$ length). They were caught between April 1977 and December 1979 near Valencia de D. Juan, in the barbel zone of the Esla River, Spain, at an altitude of $748 \mathrm{~m}$. The gradient of the stretch was $1.46 \%$, mean annual temperature 10 to $12^{\circ} \mathrm{C}$ and annual rainfall 400 to $500 \mathrm{~mm}$.

After necropsy, smears of organs were examined. Myxosporean spores and trophozoites were observed and measured on fresh material. Slides of spores treated with black Indian ink or with a satured solution of urea were prepared. Histological slides stained with haematoxylin and eosin ( $\mathrm{H} \& \mathrm{E}$ ) or by the Van Gieson's method were also prepared.

Infection intensity was semiquantitatively evaluated on a scale of + to +++++ , according to the number of spores or plasmodia per field.

\section{RESULTS}

\section{Description}

Spores of Myxidium rhodei were elongated, ellipsoidal, with somewhat pointed ends, and measured 10.5 to $15 \mu \mathrm{m}(\overline{\mathrm{x}}=12.1 ; \mathrm{SD}=0.8343)$ long by 4 to $6 \mu \mathrm{m}(\overline{\mathrm{x}}=$ $5.1 ; \mathrm{SD}=0.5551)$ wide and 5 to $5.5 \mu \mathrm{m}(\overline{\mathrm{x}}=5.2 ; \mathrm{SD}=$ $0.3535)$ thick. Each valve displayed 9 to 11 longitudinal ridges (Figs. 1 to 3). Spores contained pear-shaped polar capsules, 2.8 to $4.5 \mu \mathrm{m}(\overrightarrow{\mathrm{x}}=3.44 ; \mathrm{SD}=0.4590) \times 2$ to $3.5 \mu \mathrm{m}(\overline{\mathrm{x}}=2.5 ; \mathrm{SD}=0.310)$, with polar filaments forming 4 to 6 coils inside. The extended filaments measured 16 to $20 \mu \mathrm{m}$. On application of black Indian ink a mucous envelope was not observed (Fig. 3). Sporoblasts were usually disporous.

Plasmodia could be observed in the kidney tissue, in fresh smears (Fig. 4) and in histological sections. They frequently appeared encysted, forming spherical or ellipsoidal granulomas measuring 66 to 185 by 66.5 to $203 \mu \mathrm{m}$. 

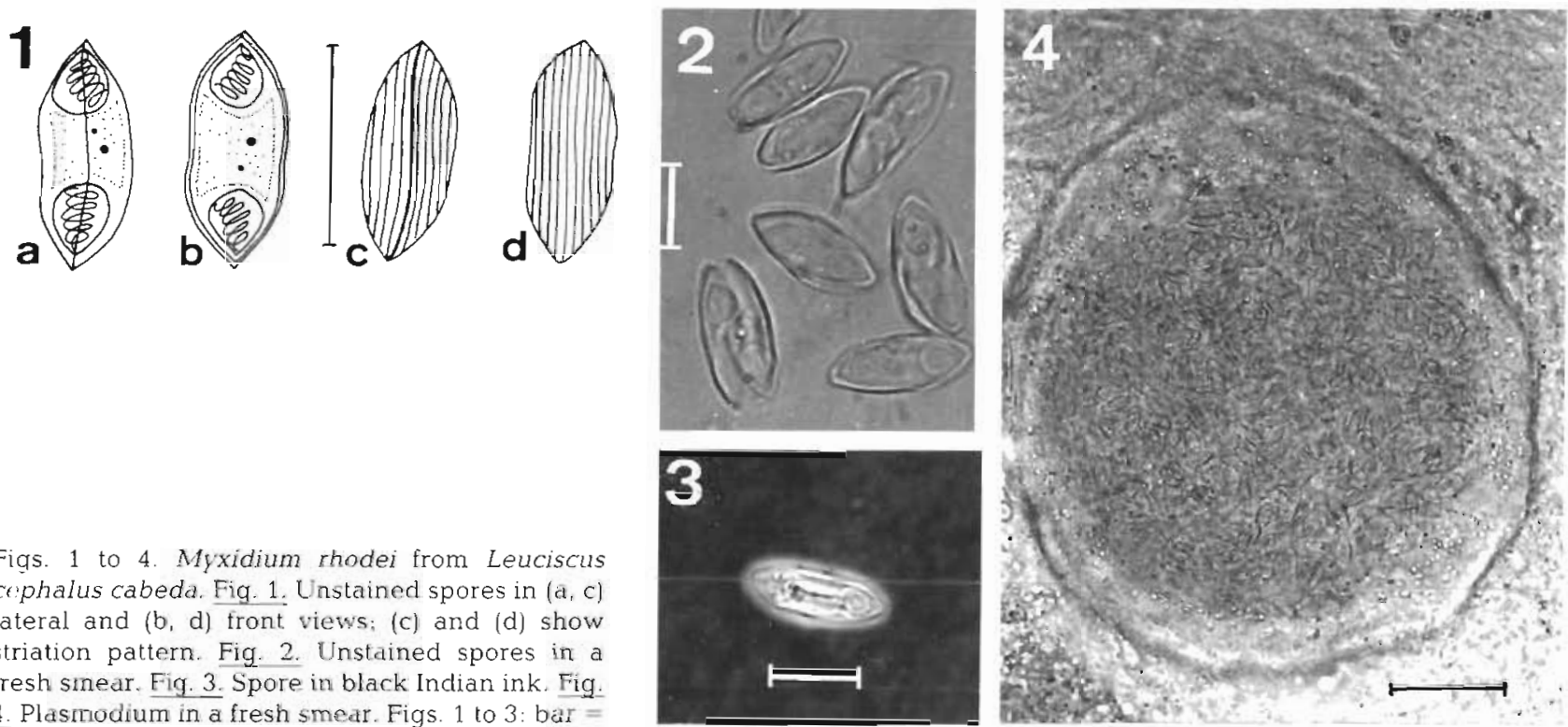

Figs. 1 to 4. Myxidium rhodei from Leuciscus criphalus cabeda. Fig. 1. Unstained spores in (a, c) lateral and (b, d) front views; (c) and (d) show striation pattern. Fig. 2. Unstained spores in a fresh smear. Fig. 3 . Spore in black Indian ink. Fig. 4. Plasnodium in a fresh smear. Figs. 1 to 3 : bar $=$ $10 \mu \mathrm{m}$. Fig. $4:$ bar $=50 \mu \mathrm{m}$

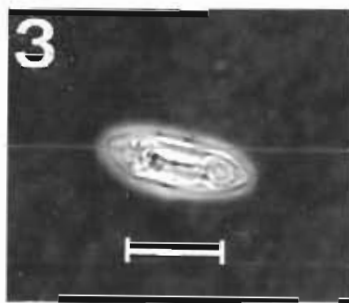

\section{DISCUSSION}

Only 3 female chubs ( 2 to 4 yrs old), caught in February, May and June, and 1 female boga (3 yr old) sampled in November, were found to be parasitized. Intensity of infection was assessed as $++t$ in chub and ++++ in boga. These fish also harboured other myxosporeans, in various organs, belonging to the genera Mrxidium, Chloromyxum and Myxobolus.

\section{Histopathology}

Spores and plasmodia of Myxidium rhodei were found only in the kidney, more frequently in the renal interstitia than in the glomeruli. Mature spores were often found encapsulated in spherical or ellipsoidal granulomas (Figs. 5 to 8) and accompanied by an intense fibrotic reaction. A granulomatous inflammatory reaction, with leucocytic infiltration, was also evident around cysts. Tissue adjacent to granulomas was sometimes atrophied (Fig. 6). On some occasions, plasmodia. cysts or groups of spores were also found associated with the melanomacrophagic centres (Fig. 8). Plasmodia in different stages of development were also found in the interstitia or glomeruli, and an inflammatory reaction around them was also evident (Figs. 9 and 10). Affected glomeruli showed thickening of the basal membrane followed by enlargement of the Bowman's capsule (Fig. 9). As a result, a great part of the renal tissue was damaged. Some tubuli also seem to have been affected, and early developmental stages may be released to the lumen (Fig. 11).
The size and shape of spores found coincide with those previously reported for Myxidium rhodei and $M$. pfeifferi (Lom 1961, Shulman 1984, Dykova et al. 1987. Kepr 1987). The 2 species are morphologically very similar and, according to Dykova et al. (1987), differ in their preferred location in the host: kidney for $M$. rhode and gall bladder for $M$. pfeifferi. Therefore, the present species must be identified as $M$. rhodei, although we agree with Dykova et al. (1987) that further investigation on the actual differences between the 2 species is required. Kepr (1987) also found trophozoites and spores of $M$. rhodei in muscle tissue and liver of roach indicating a wider specificity of location.

Although the myxosporean has been reported from fishes of the genus Leuciscus, this is the first record in Leuciscus cephalus cabeda and also the first in a fish of the genus Chondrostoma.

The prevalence we observed is clearly lower than that reported by Dykova et al. (1987) for Bulgarian and Czechoslovakian roach. Nevertheless, chub and boga of the same origin harbour other myxosporeans with clearly higher prevalences: regarding Myxidium spp., the gall bladder of both hosts may be parasitized by $M$. macrocapsulare (Alvarez-Pellitero et al. 1983) but we have never found $M$. pfeifferi here.

Myxidium rhodei was never found in other cyprinid species from the same area. On the other hand, the 2 Leuciscinae, chub and boga, also share other parasite species (Alvarez-Pellitero et al. 1983)

Our histopathological results coincide with those reported by Dykova et al. (1987) for roach in the sever- 

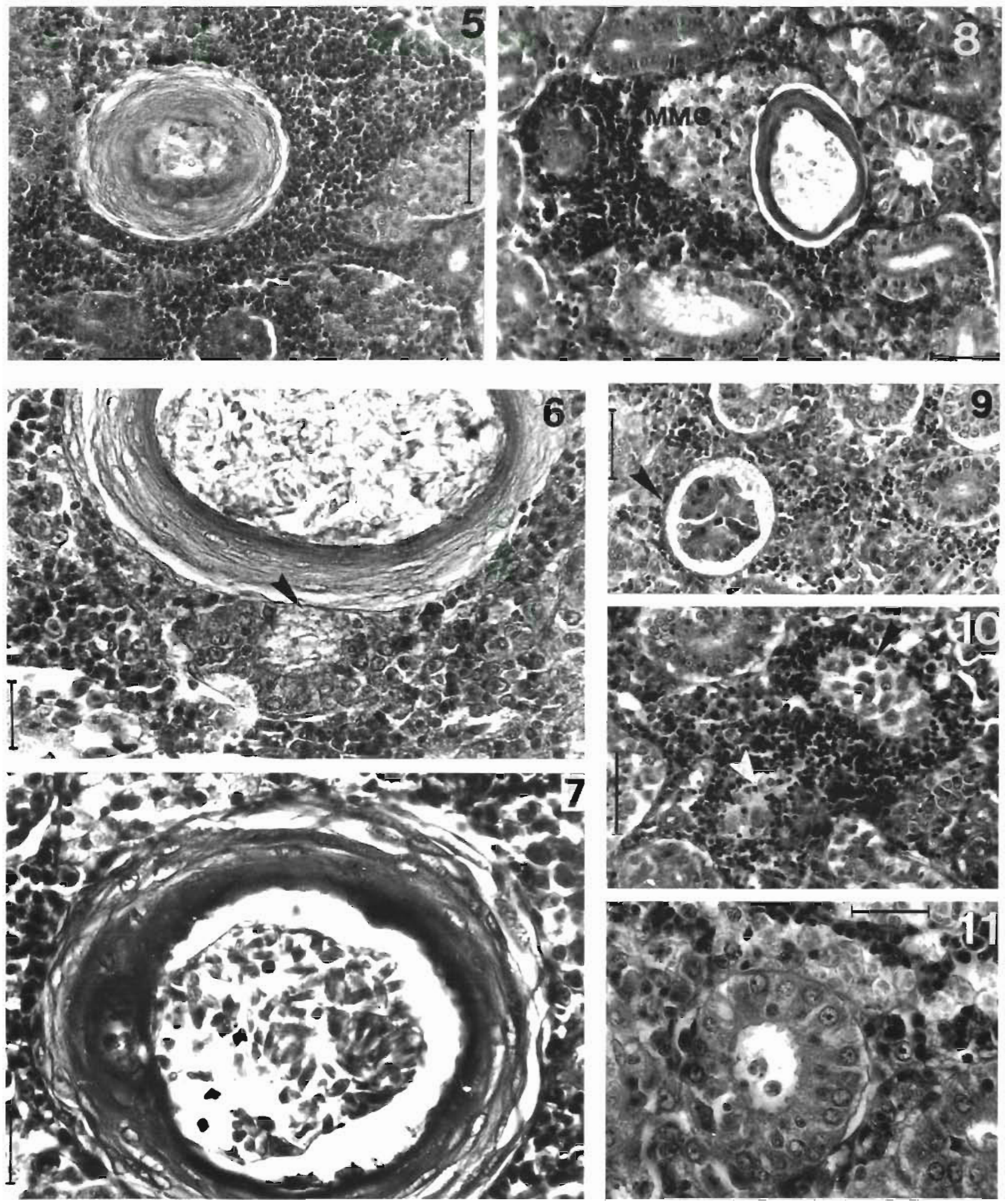

Figs. 5 to 11. Myxidium rhodei from the kidney of Leuciscus cephalus cabeda. Figs. 5 to 8. Granulomas containing spores, with intense fibrotic reaction and leucocitary infiltration. Note the destruction of the tubular tissue by pressure atrophy in Fig. 6 (arrow) Fig. 9. Affected glomerulus (arrow) with thickening of the basal membrane and increasing of the extracapillary space. Fig. 10 Plasmodia (arrows) in the interstitia; note the leucocytic infiltration. Fig. 11. Affected tubule with early plasmodia in the lumen. MMC: melanomacrophagic centres. Figs. 5,8 to 10 : bar $=50 \mu \mathrm{m}$. Figs. $6,7,11$ : bar $=20 \mu \mathrm{m}$. Stainings: Figs. 5, 6, 8 to $11 \cdot \mathrm{H} \& \mathrm{E}$ 
ity of kidney damage and the extensive inflammatory changes. However, we observed plasmodia or cysts with mature spores more frequently in the interstitia than in the glomeruli, with subsequent damage to the hematopoietic tissue. Granulomas with an intense fibrotic reaction were also seen more frequently, as well as an intense granulomatous inflammatory reaction around affected glomeruli. Moreover, Dykova et al. (1987) did not describe infection in the renal tubuli, but Ventura \& Paperna (1984) found plasmodia of Myxidium giardi in the epithelium of renal tubuli of affected elvers, in which pathological damage may be severe, in contrast to older eels. Copland (1983) however, considers the lesions produced by $M$. giardi in the kidney of young eels to be minimal, although he observed granulomatous changes in other organs such as spieen and fat. This situation contrasts with that described for Myxidium rhodei by Dykova et al. (1987) and in this paper. The observed differences in the pathological effects of this myxosporean may depend on the host species, its age or other conditions. If the synonymity of $M$. rhodei and $M$. pfeifferi could be definitively demonstrated, the severity of damage observed in the kidney might perhaps be due to the fact that this tissue is not the normal site of infection by the protozoan. Further research on the pathological effects of the myxosporeans should clarify the importance of this group of protozoan parasites to their fish hosts.

Responsible Subject Editor: Professor W. Körting, Hannover, F.R. Germany
Acknowledgements. We thank Dr Gonzalez-Lanza from the Estación Agricola Experimental de Leon (CSIC) for processing the data, and Miss Ferreras and Miss Sitjá Bobadilla for their collaburation in the preparation of histological scctions. This work was supported by research grant $\mathrm{C} 2 / 80$ from the CAICYT, Spain

\section{LITERATURE CITED}

Alvarez-Pellitero, Ma. P., Pereira-Bueno. J. Ma., GonzálezLanza, Ma. C. (1983). Celozoic myxosporeans (Myxidium spp. and Chloromyxum spp.) of cyprinids from the river Esla (León, NW Spain). I. Description of the species. Angew. Parasit. 24: 1-14

Copland, J. M. (1983). The pathology of Myxidium giardi Cépède, 1906 infections in wild and cultured eels, Anguilla anguilla L. J. Fish Dis. 6: 451-460

Dykova. I., Lom, J., Grupcheva, G. (1987). Pathogenicity and some structural features of Myxidium rhodei (Myxozoa: Myxosporea) from the kidney of the roach Rutilus rutilus. Dis. aquat. Org. 2: 109-115

Jayarsi, M., Hoffman, G. L. (1982). Review of Myxidium (Protozod: Myxozoa: Myxosporea). Protozool. Abstr. 6: 61-91

Kepr, T (1987). Myxidium rhodei Léger, 1905 (Protozoa: Myxosporea) in the muscle and liver tissue of the roach, Rutilus rutilus (L.). Folia Parasitol. 34: 181-182

Lom, J. (1961). Prispevek k poznani parasitisckych prvoko nasich ryb I. Myxosporidia, Suctoria. Zool. Listy 24: 45-58

Shulman, S. S. (1984). Parasitic Protozoa. In: Bauer, O. N. (ed.) Key to determination of the parasites of freshwater fish of the USSR, Vol. 1. Nauka, Leningrad, p. 426 (Russian)

Ventura, M. T., Paperna, I. (1984). Histopathology of Myxidium giardi Cépède 1906 infection in European eels, Anguilla anguilla L. in Portugal. Aquaculture 43: 357-368

Manuscript first received: December 20, 1988

Revised version accepted: June 5, 1989 